\title{
New Group Counseling Competencies Scale-Short Form to Supervise Group Counselor Candidates
}

\author{
(New Group Counseling Competencies Scale-Short Form untuk Menyupervisi Calon Konselor \\ Kelompok) \\ Agus Taufiq ${ }^{1 *}$, Herdi Herdi \\ ${ }^{1}$ Psychology Education and Counseling Department, Faculty of Education, Universitas Pendidikan Indonesia, \\ Dr. Setiabudi St. No. 229 Bandung, West Java, 40154 Indonesia \\ ${ }^{2}$ Department of Guidance and Counseling, Faculty of Education, Universitas Negeri Jakarta, \\ Rawamangun Muka St., East Jakarta, Special Capital Region of Jakarta, 13220 Indonesia \\ *corresponding author, email: afiq@upi.edu
}

Article received: April $1^{\text {st }} 2020$; revised: May 21 ${ }^{\text {st }} 2020$; accepted: May $26^{\text {th }} 2020$

\begin{abstract}
Assessment of Group Counseling Competencies Scale (AGCCS) is one of the questionnaires important to assess group counseling competencies. The objective of this study is to adopt and test the psychometric properties of New Group Counseling Competencies Scale-Short Form (NGCCS-SF). This study used a new instrument adaptation procedure. A total of 73 candidates of group counselors from two Study Program of Guidance and Counseling in Indonesia were the participants of this study. The data of group counseling competencies were measured using NGCCS-SF. Operationally, data analysis used Rasch Model 3.75. The results of the study show that NGCCS-SF has satisfying psychometric properties. NGCCS-SF can be used as an effective and valid assessment tool for group counselor candidates in counselor education and supervision in Indonesia.
\end{abstract}

Keywords: group counselor candidates; group counseling competencies; Group Counseling Competencies Scale; counselor education and supervision

\begin{abstract}
Abstrak: AGCCS menjadi salah satu kuesioner yang penting untuk menilai kompetensi konseling kelompok. Tujuan penelitian ini untuk mengadaptasi dan menguji properti psikometrik NGCCS-SF . Penelitian ini menggunakan prosedur adaptasi instrumen baru. Sebanyak 73 calon konselor kelompok dari dua Program Studi Bimbingan dan Konseling di Indonesia menjadi partisipan penelitian. Data kompetensi konseling kelompok diukur menggunakan $N G C C S-S F$. Secara operasional, analisis data menggunakan Rasch Model 3.75. Hasil penelitian menunjukkan bahwa NGCCS-SF memiliki properti psikometrik yang memuaskan. $N G C C S-S F$ dapat menjadi alat asesmen calon konselor kelompok yang efisien dan valid dalam pendidikan dan supervisi konselor di Indonesia.
\end{abstract}

Kata kunci: calon konselor kelompok; kompetensi konseling kelompok; Group Counseling Competencies Scale; pendidikan dan supervisi konselor 


\section{INTRODUCTION}

The excellent and professional performance of the group counselor is influenced by group counseling competencies. Group counseling contains therapeutic properties which allow the counselee to broaden knowledge for self-development and social competence, as well as to understand, explore, and solve problems effectively and efficiently. (Corey, Corey, \& Corey, 2014; Jacobs, Masson, Harvill, \& Schimmel, 2012). Other experts suggest that the urgency of group counseling is: giving the opportunity to open up and redefining themselves, finding themselves and others, developing intra-personal awareness and testing self-reality and others, and it is proven as effective (Berg, Landreth, \& Fall, 2018).

Empirical studies show that group counseling is an important element of the school counseling program and it is proven as an effective intervention when it is applied in the school setting (Akos, Goodnough, \& Milsom, 2004) and other setting (Erford, 2017). Other studies show that group counseling is significantly positive affecting self-awareness, automatic thinking, and emotional regulation (Erden, 2015), trust in other people (Gültekin, Erkan, \& Tüzüntürk, 2011), social competence (Ateş, 2016; Cheng \& Ray, 2016), and self-efficacy in education (Mohammadib, Sohrabia, \& Aghdamc, 2013). Recent studies find that group counseling/psychotherapy based on bibliotherapy and creative writing is effective in developing well-beingness in adults since it provides a unique room for them to share feelings, acceptance, challenge, and inspiration (Malyn, Thomas, \& Ramsey $\square$ Wade, 2020). Group counseling is also effective in reducing anxiety before an exam (Zarei, Fini, \& khajehzadeh Fini, 2010), reducing depression symptoms in adolescence (Karami, Ghasemzadeh, Saadat, Mazaheri, \& Zandipour, 2012)and adult patients (Zajenkowska, Barycka, \& Chotkowska, 2020).

In the Association of Counseling, Education and Supervision (ACES) and Council for Accreditation of Counseling \& Related Educational Programs (CACREP), it is important to develop group counseling competencies as one of the core competencies of a counselor candidate of the program counselor education and supervision (ACES, 2011; CACREP, 2016; Kementerian Pendidikan Nasional, 2008; Ohrt et al., 2014). In Indonesia, group counseling is considered and viewed as important, more effective and efficient than individual counseling since the ration between the counselor and counselee at school is 1: 150 (Kementerian Pendidikan Nasional, 2014). Previous studies show that group counseling is proven to be effective than individual counseling to be applied in a school setting (Pérusse, Goodnough, \& Lee, 2009). Similar studies report that group counseling/psychotherapy is more effective than individual counseling in addressing attention disorder and hyperactive (Philipsen et al., 2015). Therefore, a counselor candidate must possess sufficient or high-level group counseling competencies. However, the previous study shows that the profile of counselor candidate in group counseling at two departments of guidance and counseling in Indonesia tend to be at a moderate level (Taufiq, Saripah, \& Herdi, 2019).

Based on this rationale, standardized measuring tools to measure group counseling competence is necessary. This effort can be a valuable tool in operationalizing meaning, mapping profiles, and designing counselor education and supervision programs to develop, identify and test the constructs of ontogenesis and consequences, as well as differences in group counseling competencies in group counselor candidates. However, there is no intensive study to adapt and develop a standardized instrument to measure group counseling competencies in group counselor candidates until now.

Assessment of Group Counseling Competencies Scale (AGCCS) (Berg et al., 2018) is one of the useful tools to assess the group counseling competency of counselor candidates. However, the large number of items takes a long time to administer, is impractical, and sometimes makes the counselor candidates unwilling to complete them. Therefore, the objective of this study is to adapt and test the psychometric properties of the New Group Counseling Competencies Scale-Short Form (NGCCS$\mathrm{SF}$ ) in a short version to be more efficient, effective, and practical in its administration. The reduction of the number of items is expected to maintain the quality of psychometric properties. Based on this rationale, this study is focused on the adaptation and testing of NGCCS-SF psychometric properties for group counselor candidates in Indonesia. The research question is: How is the overview of NGCCS-SF psychometric properties for group counselor candidates in Indonesia? 


\section{METHOD}

This study used the standard instrument adaptation and validation procedures of the International Test Commission ("ITC Guidelines for Translating and Adapting Tests (Second Edition)," 2018). This method was chosen because this study aimed at adapting and testing the psychometric properties of the standard instruments of the NGCCS-SF for supervised group counselor candidates.

The participants were 73 supervised group counselor candidates from two Department of Guidance and Counseling in Indonesia. It was based on the opinion of experts that a minimum number of participants of 30-50 people was eligible/adequate for a pilot study to produce stable estimation results on the scale of \pm 1 logit (Linacre, 2019; Sumintono \&Widhiarso, 2015).

The research instrument was AGCCS (Berg et al., 2018) containing 115 items in the form of 5-point Likert scale, with $1=$ very low to $5=$ very high. AGCCS is developed and used by three group counseling experts: Robert C. Berg, Garry L. Landreth, and Kevin A. Fall since 2006-2018 based on the construct of group counseling competencies they developed. This instrument was also congruent with group counseling competency standards and was widely used by CACREP (2016) and Association for Specialists in Group Work (ASGW) (Berg et al., 2018) to measure the competency of counselors and group worker specialist, both the counselor candidates who were attending the counselor education and supervision program as well as school counselors. However, based on the searching results from various research databases, the study report on the adaptation and testing of AGCCS psychometric properties was still limited.

Adaptation procedures of AGCCS followed the general guidelines for instrument adaptation of the International Test Commission ("ITC Guidelines for Translating and Adapting Tests (Second Edition)," 2018) that was: "translating, editing, and retranslating by a different professional translator." The following step was choosing 31 of 115 items to be an NGCCS-SF and testing them out to the supervised group counselor candidates in two Department of Guidance and Counseling in Indonesia. The last stage was analyzing the results of the NGCCS-SF trial based on the Item Response Theory (IRT) approach using the Rasch Model v. 3.73.

The data analysis included various item feasibility tests (item measure, item fit order, and differential item functioning (DIF)), ability of participants (person measure and person fit order), instrument quality analysis (unidimensionality and rating scale), and reliability (test reliability, person reliability, item reliability). The tests usedthe Item Response Theory (IRT) approach, which was the Rasch Model with Winsteps 3.73 .

\section{RESULTS}

\section{Item Feasibility}

The first question about the overview of NGCCS-SF item feasibility was analyzed from the criteria of item measure, item fit order, and DIF using the Rasch Model. First, the item measure was used to measure the difficulty level of the item. As presented at table 1, the results of the item measure test showed that the S13 item with +2.43 logit was the most difficult item to be approved by the participants, while the S23 item with the value of -1.49 logit was the easiest item to approve. Second, the fit order item was used to test items that are fit and misfit. The results revealed that all (31) items were fit. Third, DIF which was used to detect bias items in particular participants categories showed that all (31) items were not biased to certain educational institutions (department of guidance and counseling). Based on the three-item feasibility criteria, all (31) items were fit and used in the NGCCS-SF version of the group counselor candidates for the counselor education and supervision program in Indonesia.

\section{Ability of Participants}

The second question about the evidence of the level of ability of the participants was analyzed from the criteria of person measure and person fit order using the Rasch Model. Person Measure test results showed that the participant number 18 (participant code 81 ) with +3.75 logits tended to have high group counseling competencies since his answers were mostly high and very high, while the participant number 43 (participant code 32 ) with a value of -2.73 logit tended to have low group counseling competencies, 
Table 1. Results of Item Feasibility Test of NGCCS-SF

\begin{tabular}{ccccccc}
\hline \multirow{2}{*}{ No. Item } & \multicolumn{5}{c}{ Types of Item Feasibility Test } \\
\cline { 2 - 6 } & Item & \multicolumn{5}{c}{ Item Fit Order } \\
\cline { 3 - 6 } & & Infit Mnsq & Outfit Mnsq & Outfit Zstd & Pt-MCorr & \\
\hline S1 & -.49 & 1.09 & 1.10 & .60 & .42 & .8692 \\
S2 & -.57 & 1.24 & 1.23 & 1.3 & .47 & .7383 \\
S3 & .47 & 1.32 & 1.33 & 1.8 & .54 & .6683 \\
S4 & 1.03 & 1.12 & 1.13 & .80 & .43 & .7976 \\
S5 & -.05 & 1.18 & 1.18 & 1.6 & .43 & .9755 \\
S6 & -1.19 & 1.28 & 1.31 & 1.8 & .50 & .9659 \\
S7 & -.01 & 1.00 & 1.00 & .10 & .58 & .8987 \\
S8 & -.01 & .89 & .89 & -.6 & .68 & .8610 \\
S9 & -.62 & .82 & .81 & -1.1 & .54 & .9902 \\
S10 & .12 & 1.00 & 1.00 & .10 & .47 & .9453 \\
S11 & .56 & .70 & .70 & -1.9 & .67 & .9860 \\
S12 & -.05 & .61 & .60 & -2.6 & .64 & .9907 \\
S13 & 2.43 & 1.08 & 1.08 & .60 & .46 & .9717 \\
S14 & .16 & 1.10 & 1.10 & .60 & .54 & .9241 \\
S15 & -.32 & .93 & .92 & -.40 & .49 & .9876 \\
S16 & .60 & .78 & .78 & -1.3 & .59 & .8166 \\
S17 & .25 & .86 & .87 & -.70 & .71 & .9275 \\
S18 & -.19 & .94 & .92 & -.40 & .69 & .9746 \\
S19 & 1.73 & 1.30 & 1.30 & 1.8 & .67 & .9629 \\
S20 & .12 & 1.05 & 1.04 & .30 & .59 & .9981 \\
S21 & .90 & 1.50 & 1.50 & 2.7 & .37 & .7057 \\
S22 & -1.02 & .58 & .58 & -3.0 & .67 & .9886 \\
S23 & -1.49 & .55 & .55 & -3.3 & .77 & .9996 \\
S24 & -1.28 & .63 & .62 & -2.7 & .77 & .9954 \\
S25 & -1.28 & .87 & .86 & -.90 & .71 & .9544 \\
S26 & .90 & 1.15 & 1.17 & 1.0 & .52 & .5616 \\
S27 & -.54 & 1.16 & 1.14 & .90 & .70 & .7718 \\
S28 & .81 & 1.24 & 1.24 & 1.4 & .45 & .7798 \\
S29 & .43 & 1.10 & 1.09 & .60 & .55 & .7359 \\
S30 & .34 & 1.02 & 1.02 & .20 & .59 & .8577 \\
S31 & -1.41 & .60 & .59 & -3.0 & .65 & .9952 \\
\hline & & & & & &
\end{tabular}

as hemostly answered with low and very low on NGCCS-SF instrument items. Person Fit Order was used to test the participants who were fit and misfit. The criteria were the same as the analysis of item fit order. Based on these criteria, six out of 73 participants were misfit.

\section{Instrument Quality}

The third question about the quality of NGCCS-SF was analyzed using the unidimensionality test, rating scale, and reliability test. Unidimensionality was analyzed with the principal component analysis (PCA) from the residual. The measurement results showed a raw variance of $56.9 \%$ and variance that could not be explained by the instruments by $6.9 \%$. Detailed results of the study are presented in Table 2 . The rating scale was used to verify the clarity of the rating scale choice in NGCCS-SF. The analysis results using the Rasch Model found that the average value of observation was started from logit -5.61 for the choice of score 1 (very low), logit -3.10 for score 2 (low), logit -.10 for score 3 (moderate), logit 
Table 2. Summary of NGCCS-SF Statistics

\begin{tabular}{lll}
\hline \multicolumn{1}{c}{ Output } & \multicolumn{1}{c}{ Result } \\
\hline \multirow{2}{*}{ Item } & Item Reliability & .94 \\
& Highest logit value & +2.43 logit (S13) \\
& Lowest logit value & -1.49 logit (S23) \\
& Person & .92 \\
& Person reliability & +3.73 logit (PNU 18; KP 81) \\
& Highest logit value & -2.73 logit (PNU 43; KP 32) \\
& Lowest logit value & .93 \\
& Cronbach's alpha & 56.9 \\
& Raw variance described by measurement & 6.9 \\
& Variance not described by the first contrast & 5.3 \\
& Variance not described by the second contrast & 4.4 \\
& Variance not described by the third contrast & \\
& Variance not described by the fourth contrast & 4.0 \\
& Variance not described by the fifth contrast & 3.6 \\
\hline
\end{tabular}

+3.09 for score 4 (high), and logit +5.80 for score 5 (very high). Similar results were also presented by Andrich Threshold who tested the feasibility of polytomy values. This value showed the movement from NONE to negative (-4.47 and -1.70) and led to positive $(+1.50$ and +4.67$)$, respectively. It means that, the choice in the rating scale is valid and appropriate and does not make the participants confuse.

Reliability. Table 2 . The summary of statistics shows person measure $=+.34$ logit. The average value that is higher than logit .0 indicates the tendency of participants to answer higher on each item. Cronbach's Alpha value to measure the reliability of the test, that is the interaction between people and items as a whole is .93 , person reliability is .92 , and item reliability is .94. Similar results are presented by Infit and Outfit Mnsq for person and item, the average values are 1.00 and .99 and .99 and .99 respectively which are close to the ideal value of 1.00. Likewise, Infit and Outfit Zstd show an average value of person and item of -.2 and -.2 and -.1 and -.1, which means good because it approaches.0.

\section{DISCUSSION}

\section{Item Feasibility}

The analysis of item feasibility of NGCCS-SF includes: item measure, item fit order, and DIF (Bond, 2015; Boone, Staver, \& Yale, 2014; Linacre, 2019; Sumintono \& Widhiarso, 2014, 2015). The measure item was used to measure the difficulty level of NGCCS-SF items. Meanwhile, the item fit order was used to identify items that were fit or misfit. The results found that all (31) NGCCS-SF items were fit to be used to collect the data about group counseling competencies. This decision was taken based on the criteria that the item was said to be fit if the Infit and Outfit Mnsq values were within the acceptable range (.5 MNSQ < 1.5), Outfit Zstd $(-2<$ Zstd $>+2)$, Pt-MCorr (.4 < pt-MCorr .85) (Bond, 2015; Boone et al., 2014; Linacre, 2019; Sumintono \& Widhiarso, 2014, 2015). From the Table 1, it was known that item S12, S21, S22, S23, S24 did not meet the Zstd criteria because they were outside the tolerance limit $(-2<$ Zstd $>+2)$, but the three other criteria were met. Under this condition, all four items were maintained as items in the NGCCS-SF.

On the other hand, DIF was used to identify NGCCS-SF items whether they were biased or not. The results showed that all items were not biased towards a certain educational institution (Department of guidance and counseling). This decision was made based on the probability value of each item that was more than $5 \%(.05)$. As we know,biased items were detected from the probability value that was less than 5\% (.05) (Bond, 2015; Dimitrov, 2014; Linacre, 2019; Sumintono \& Widhiarso, 2014, 2015).

\section{Ability of Participants}

The analysis of the ability of participants is important as well as the item feasibility analysis of NGCCS-SF, including measure item and fit order item. The analysis can help the counselor/supervisor educators to identify which counselor candidates who have a high or low level of competency, counselor candidates who have different response patterns due to carelessness, guessing, or work together in completing the NGCCS-SF. The person fit order is used to test the participants who are fit and misfit. 
The results show that six out of 73 participants are misfit. This is based on the decision-making criteria: the ability of participants is said to be fit if the Infit and Outfit Mnsq values are within the acceptable range (.5 MNSQ < 1.5), Outfit Zstd (-2 < Zstd > +2), Pt-MCorr (.4< pt-MCorr .85) (Bond, 2015; Boone et al., 2014; Linacre, 2019; Sumintono \& Widhiarso, 2014, 2015). On the other hand, the participants who did not meet these criteria were concluded to be a misfit.

\section{Instrument Quality}

The quality of NGCCS-SF instrument was identified by conducting tests such as: unidimensionality, rating scale, and reliability test. First, unidimensionality was analyzed using the principal component analysis (PCA) of the residual by measuring the level of uniformity of the instrument in measuring what had to be measured (Linacre, 2019; Sumintono \& Widhiarso, 2014, 2015). In the development and adaptation of the instrument, unidimensionality was a prerequisite that had to be met. The measurement results showed a raw variance of $56.9 \%$ and a variance that could not be explained by the instrument of $6.9 \%$. It means that the minimum unidimensionality requirement of $20 \%$ and the variance that cannot be explained by the instrument $\leq 15 \%$ are met(Bond, 2015; Linacre, 2019; Sumintono \& Widhiarso, 2014, 2015).

NGCSS-SF is proven to measure the unidimensional construct of group counseling competencies. Group counseling experts (Berg et al., 2018), accreditation institutions (CACREP, 2016), and ASGW (Berg et al., 2018) identified ten sub-competencies of group counseling that must be mastered by professional and effective group counselor (candidates), which are able to: (1) choose individual vs. group counseling scenes appropriately; (2) apply the principles of group dynamics; (3) understand the theories and main characters of group counseling; (4) understand the history of group counseling; (5) differentiate various types of group counseling activities; (6) master the group development system; (7) master the stages and strategies of group counseling; (8) aware of various roles in group counseling; (9) familiar with research in group counseling; and (10) aware and adhere to code of ethics in group counseling. These sub-competencies constitute an integrated group counseling competencies that are required and must be mastered by professional and effective group counselors (candidates).

The second prerequisite of the quality of NGCCS-SF instrument is the rating scale. The rating scale is a set of statement categories expressing an attitude, feeling, or perception about something (Dimitrov, 2014). It is important to analyze and use to verify the ranking choice used in the NGCCS-SF whether or not it creates confusion on the participants (Bond, 2015; Linacre, 2019; Sumintono \& Widhiarso, 2014, 2015). The rating scale in an instrument is important to be prepared and analyzed since it has practicality value and the purpose to place the subjects/participants on an assessment continuum so that the relative position of the participants according to the measured attribute (group counseling competencies) can be achieved (Azwar, 2013). The analysis results using the Rasch Model show that the average observation value and the Andrich Threshold value move from NONE to negative and lead to positive, sequentially. It means that the choice of ranking scale is valid and appropriate and does not confuse the participants.

The third prerequisite for NGCCS-SF quality tested was reliability. The results showed that the Alpha Cronbach test instrument (interaction between person and item), person reliability, and item reliability were categorized as excellent/very good. In other words, it can be seen that the consistency of the answers and the test instrument is very good/excellent (Sumintono \& Widhiarso, 2014, 2015). This result far exceeds the consensus of psychometric experts that a minimum acceptable test reliability index is .70. Reliability is one of the key concepts in measurement and it plays an important role in determining the quality of the instrument and the validity of the data collected (Dimitrov, 2014).

Reliability indicates the level of accuracy, consistency, and replicability of a set of instruments, when: (1) different people take the measurement; (2) different instruments are used to measure the same attributes; and (3) there are incidental variations in the measurement condition (Dimitrov, 2014).

Based on these findings and discussion, it is known that NGCCS-SF meets the criteria for excellent/ very good items feasibility, the ability of participants, unidimensionality, rating scale, and reliability so that it can be used to measure group counseling competencies of group counselor (candidates) in counselor education and supervision program in Indonesia. However, there is no AGCCS study from the experts and other researchers that can be used as a comparison of the result of NGCCS-SF psychometric properties in this study. 


\section{CONCLUSION}

This research produced an NGCCS-SF to measure group counseling competencies in supervised group counselor candidates in the Counselor Education and Supervision Program in Indonesia with satisfactory psychometric properties. It is proven from the criteria for item measure, item fit order, and DIF, person measure, person fit order, unidimensionality, rating scale, reliability test, person reliability, and item reliability. As many as 31 NGCSS-SF items were produced to reveal group counseling competencies of the group counselor candidates in Indonesia. Further studies are needed to develop and test the NGCCS-SF with confirmatory factor analysis in a wider range of participants, both in group counselor candidates and school counselors by taking into account the ethno-socio-demographic proportion.

\section{ACKNOWLEDGMENT}

A sincere appreciation is rewarded to the study participants, as well as those who assisted in the publication of this article.

\section{REFERENCES}

ACES. (2011). Association of counselor education and supervision. Alexandria, VA: Author.

Akos, P., Goodnough, G. E., \& Milsom, A. S. (2004). Preparing school counselors for group work. The Journal for Specialists in Group Work, 29(1), 127-136.

Ateş, B. (2016). The effect of solution-focused brief group counseling upon the perceived social competences of teenagers. Journal of Education and Training Studies, 4(7), 28-36.

Berg, R. C., Landreth, G. L., \& Fall, K. A. (2018). Group counseling: concepts and procedures (6th ed.). New York: Routledge.

Bond, T. (2015). Applying the Rasch model: Fundamental measurement in the human sciences. Routledge.

Boone, W. J., Staver, J. R., \& Yale, M. S. (2014). Rasch analysis in the human sciences. Dordrecht: Springer.

CACREP. (2016). 2016 CACREP standards. Alexandria, VA: Author.

Cheng, Y.-J., \& Ray, D. C. (2016). Child-centered group play therapy: Impact on social-emotional assets of kindergarten children. The Journal for Specialists in Group Work, 41(3), 209-237.

Corey, M. S., Corey, G., \& Corey, C. (2014). Groups: Process and practice (9th ed.). Belmont, CA: Brooks/Cole.

Dimitrov, D. M. (2014). Statistical methods for validation of assessment scale data in counseling and related fields. John Wiley \& Sons.

Erden, S. (2015). Awareness: The effect of group counseling on awareness and acceptance of self and others. Procedia-Social and Behavioral Sciences, 174, 1465-1473.

Erford, B. T. (2017). Group work: Process and applications. In B. T. Erford (Ed.), Group Work (pp. 105-117). Routledge.

Gültekin, F., Erkan, Z., \& Tüzüntürk, S. (2011). The effect of group counseling practices on trust building among counseling trainees: From the perspective of social network analysis. Procedia-Social and Behavioral Sciences, 15, 2415-2420.

ITC Guidelines for Translating and Adapting Tests (Second Edition). (2018). International Journal of Testing, 18(2), 101-134. https://doi.org/10.1080/15305058.2017.1398166

Jacobs, E. E., Masson, R. L. L., Harvill, R. L., \& Schimmel, C. J. (2012). Group counseling: Strategies and skills (7th ed.). Belmont, CA: Brooks/Cole.

Karami, S., Ghasemzadeh, A., Saadat, M., Mazaheri, E., \& Zandipour, T. (2012). Effects of group counseling with cognitive-behavioral approach on reducing divorce children's depression. Procedia-Social and Behavioral Sciences, 46, 77-81.

Kementerian Pendidikan Nasional. (2008). Permendiknas No. 27 Tahun 2008 tentang Standar Kualifikasi Akademik dan Kompetensi Konselor. Jakarta: Depdiknas.

Kementerian Pendidikan Nasional. (2014). Permendikbud RI No. 111 Tahun 2014 tentang Pedoman penyelenggaraan bimbingan dan konseling di jalur pendidikan formal. Jakarta: Depdiknas.

Linacre, J. M. (2019). A user's guide to Winsteps Ministep Rasch-model computer programs. Chicago: Winsteps. com. 
Malyn, B. O., Thomas, Z., \& Ramsey $\square$ Wade, C. E. (2020). Reading and writing for well $\square$ being: A qualitative exploration of the therapeutic experience of older adult participants in a bibliotherapy and creative writing group. Counselling and Psychotherapy Research, capr.12304. https://doi.org/10.1002/capr.12304

Mohammadib, R., Sohrabia, A., \& Aghdamc, G. A. (2013). Effectiveness of group counseling with problem solving approach on educational self-efficacy improving. Procedia-Social and Behavioral Sciences, 84, 1782-1784.

Ohrt, J. H., Ener, E., Porter, J., \& Young, T. L. (2014). Group leader reflections on their training and experience: Implications for group counselor educators and supervisors. The Journal for Specialists in Group Work, 39(2), 95-124.

Pérusse, R., Goodnough, G. E., \& Lee, V. V. (2009). Group counseling in the schools. Psychology in the Schools, 46(3), 225-231.

Philipsen, A., Jans, T., Graf, E., Matthies, S., Borel, P., Colla, M., ... Groß-Lesch, S. (2015). Effects of group psychotherapy, individual counseling, methylphenidate, and placebo in the treatment of adult attentiondeficit/hyperactivity disorder: a randomized clinical trial. JAMA Psychiatry, 72(12), 1199-1210.

Sumintono, B., \& Widhiarso, W. (2014). Aplikasi model Rasch untuk penelitian ilmu-ilmu sosial (2nd ed.). Trim Komunikata Publishing House.

Sumintono, B., \& Widhiarso, W. (2015). Aplikasi pemodelan Rasch pada assessment pendidikan. Trim komunikata.

Taufiq, A., Saripah, I., \& Herdi, H. (2019). The Role of Education and Supervision toward the Candidates of Group Counselor Competencies. In 3rd Asian Education Symposium (AES 2018) (pp. 118-122). Atlantis Press.

Zajenkowska, A., Barycka, J., \& Chotkowska, K. (2020). Borderline personality disorder level predicts change in depressiveness after short $\square$ term group psychotherapy: A study in a daily psychiatric clinic. Counselling and Psychotherapy Research, 20(2), 380-384.

Zarei, E., Fini, A. A. S., \& khajehzadeh Fini, H. (2010). A comparison of effect of group counselling methods, behavioural, cognitive and cognitive-behavioural to reduce students test anxiety in the University of Hormozgan. Procedia-Social and Behavioral Sciences, 5, 2256-2261. 